Early Printed Narrative Literature in Western Europe 



\section{Early Printed Narrative Literature in Western Europe}

Edited by

Bart Besamusca, Elisabeth de Bruijn and Frank Willaert 
ISBN 978-3-11-056300-9

e-ISBN (PDF) 978-3-11-056301-6

e-ISBN (EPUB) 978-3-11-056310-8

\section{(cc) BY-NC-ND}

This work is licensed under a Creative Commons Attribution-NonCommercial-NoDerivatives 4.0 International License. For details go to https://creativecommons.org/licenses/by-nc-nd/4.0/.

\section{Library of Congress Control Number: 2019938240}

\section{Bibliographic information published by the Deutsche Nationalbibliothek}

The Deutsche Nationalbibliothek lists this publication in the Deutsche Nationalbibliografie; detailed bibliographic data are available from the Internet at http://dnb.dnb.de.

(C) 2019 Bart Besamusca, Elisabeth de Bruijn and Frank Willaert, published by Walter de Gruyter GmbH, Berlin/Boston

The book is published with open access at www.degruyter.com.

Cover image: Western Europe in the sixteenth century. Source: Abraham Ortelius, Theatre, oft: Toonneel des aerdtbodems waer in te siene sijn die landt-tafelen der geheelder weerelt, met een corte verclaringe der selver. Printed by Gielis van Diest (Antwerp, 1571), copy: Museum Plantin-Moretus: Preciosa, R 39.7. Design: Typografie Frederik Hulstaert Typesetting: Integra Software Services Pvt. Ltd. Printing and binding: CPI books $\mathrm{GmbH}$, Leck 